\title{
SENTINEL LYMPH NODE CONCEPT IN DIFFERENTIATED THYROID CANCER
}

\author{
Markovic Ivan, Dzodic Radan \\ Medical faculty University of Belgrade, Institute of oncology and radiology of Serbia, Belgrade, Serbia \\ Primljen/Received 15. 11. 2014. god. \\ Prihvaćen/Accepted 15. 12. 2014. god.
}

Abstract: Introduction: Differentiated thyroid carcinoma (DTC) account up to $90 \%$ of all thyroid malignacies, and represents the most common malignant tumors of endocrine system. The incidence of papillary thyroid carcinoma (PTC), especially small tumors is rapidly increasing during past three decades. At the time of diagnosis, the incidence of lymph node metastases (LNM) ranges from 80 to $90 \%$. During the last 15 years, LNM were recognized as bad prognostic factor for both local-regional relapse (LRR) and cancer specific survival. There is general agreement that neck dissections are indicated in cases of clinically apparent LNM. The subject of the current controversy is the surgical treatment of occult LNM that remain unrecognized on preoperative diagnosis $(\mathrm{cN} 0)$. The extent of operations of the lymph nodes ranges from "wait and see" so-called "Western school" principle substantiated the role of applying ablative I131 therapy and frequency peroperative complications (recurrent laryngeal nerve injury and hypoparathyroidism), especially for less experienced teams to mutual prophylactic dissection of the central and lateral compartments so-called "Japanese school" due to the limited use of radioactive iodine therapy and significantly lower operating morbidity if dissetion was done during primary operation. Despite high prevalence of occult LNM, existing controversies regarding diagnosis, longterm prognostic impact and extent of lymph node surgery, motivated some authors to apply consept of sentinel lymph node biopsy (SLNb) in DTC, taking into account excellent results of SLN concept in breast cancer and skin melanoma. This review presents the summarized results of relevant studies and three meta-analysis of accuracy and applicability of SLN concept in patients with differentiated thyroid carcinoma.

Key words: Differentiated thyroid cancer, lymph node mestastases, sentinel lymph nodes.

\section{INTRODUCTION}

Thyroid cancer represents about $1.7 \%$ of all malignancies in humans. Survival of patients is favorable, but the disease and its treatment carries out morbidity and mortality (1). Differentiated thyroid carcinoma (DTC) account $90 \%$ of all thyroid malignancies and are the most common primary malignancy of the endocrine system, and their incidence is increasing.

Papillary thyroid carcinoma (PTC) metastasized to the regional lymph nodes in 30 to $80 \%$ of patients and up to $90 \%$ of children and adolescents. Metastasizes to the central (pretracheal and paratracheal, level VI), upper mediastinal (level VII) and lateral (supraclavicular, jugulocarotid, level II, III, IV and V) lymph nodes of the neck. Follicular thyroid carcinoma extremela rare metastasize to the lymph node, but often metastasize to distant organs such as the lungs and bones.

Lymph nodes in the neck are most commonly classified by the American Academy of Otolaryngology and the American Joint Committee on Cancer reccomendation. According to this classification, lymph nodes of the neck were divided into seven groups or levels (Figure 1).

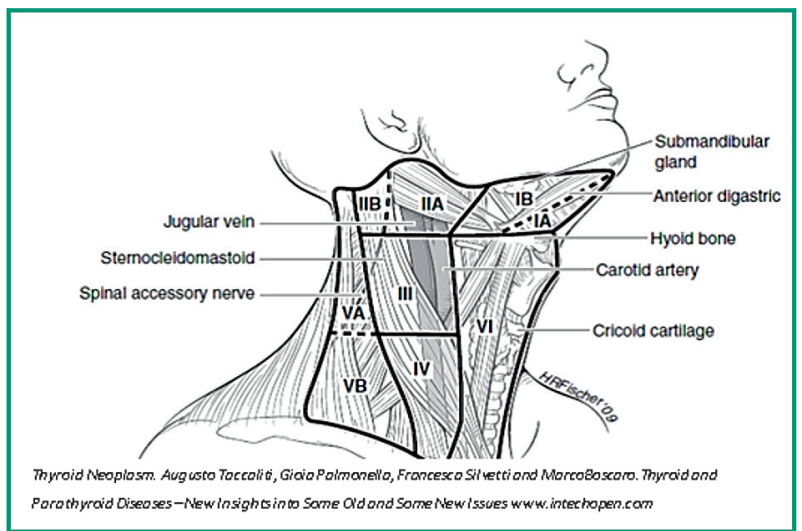

Figure 1. Neck lymph node levels 
At the time of the first clinical presentation, 20 to $30 \%$ of patients with papillary thyroid carcinoma (PTC) has metastatic lymph nodes in the neck, and around $90 \%$ have micrometastases in lymph nodes $(2,3)$.

Although very common, lymph node metastasis (LNM) are just in recent 15 years recognized as a factor of poor cancer-specific outcome $(4,5)$. Despite the fact that lymph node metastases have a high prevalence, the patients with PTC have an excellent prognosis. In the past few decades, LNM were not considered a significant factor for overall survival of patients and were the subject of numerous controversies.

Finally, in the last two decades LNM are recognized as a negative prognostic factor for disease recurrence and cancer-specific survival, especially for older patients with large tumors and extra-thyroid extension $(6,7,8)$.

Impact of LNM to disease recurrence is certainly less controversial. The existence of LNM significantly increases the rate of locoregional recurrence. Moreover, recurrence or rest of tumor in the neck after apparently curative surgery remains a major cause of morbidity and represents a significant therapeutic challenge for clinicians (9). Despite the best efforts of therapy, 10 to $30 \%$ of patients with DTC develop locoregional recurrence after the initial surgery, causing an increase in morbidity. Numerous studies have shown that relapses are the most common in lymph nodes. Therefore, surgery is a key therapeutic modality in the treatment of DTC. Total or near total thyroidectomy is standard in the treatment of primary thyroid carcinoma. Therapeutic dissection of central or lateral neck compartments is indicated in patients with clinically suspected or cytologically or histologically proven lymph node metastases (10).

The procedure with occult LNM, which are radiologically undetectable (clinically N0, cN0) is still controversial, considering the high prevalence of histologically proven micrometastases in prophylactic dissections.

American Thyroid Association (ATA) in its most recent review (2009) recommends prophylactic central neck dissection (CND) in cN0 and advanced tumors (T3 and T4). ATA also admits that avoiding the central dissection in the case of smaller tumors, "may increase the risk of locoregional recurrence, but in total can be safer in the hands of unexperienced surgeon" because of higher rates of morbidity (recurrent laryngeal nerve injury and hypoparathyroidism) when working together with total thyroidectomy $(2,11)$.

In Europe and the United States prophylactic lateral neck dissection is not routinely done because of the role of ablative radioactive iodine therapy $(2,12)$.

On the other hand, some European authors, especially some Japanese say that the prophylactic lateral neck dissection improves prognosis. According to recently published reccomendations of Japanese Association of thyroid surgeons and the Japanese Association of Endocrine Surgeons, CND in papillary thyroid cancer is standard, and prophylactic modified radical neck dissection (MRND) is routinely applied in most centers dealing with endocrine surgery in Japan $(6,7,13$, 14).

Current controversies in the surgical approach and prognostic significance of lymph node metastases, as well as the limitations of preoperative diagnosis and adjuvant therapy, has led some authors to apply the concept of sentinel lymph nodes (SLN) in patients with DTC.

\section{SENTINEL LYMPH NODES - HISTORICAL REVIEW}

Sentinel lymph node is the first lymph node/s in the corresponding lymph drainage area that receives afferent lymphatic drainage of malignant tumors. Gould and colleagues, from Washington Hospital Center, in 1960, were the first to use the term sentinel lymph node of nearest lymph node within parotidectomy for cancer of the parotid gland (15).

The concept of SLN and its predictive value in the staging of regional spread of malignant tumors, is most commonly associated with Ramon Cabanas, South African surgeon, and his pioneering work (1977) on lymphatic drainage using vital dye injection in 100 patients with carcinoma of the penis (16).

Although Cabanas first demonstrated the usefulness of this concept, many authors in the last 100 years have investigated and documented the concept of sentinel lymph nodes in different malignat tumors.

\section{THE CONCEPT OF SENTINEL LYMPH NODES}

The assumption is that the existence or absence of metastasis in the SLN expected to reflect the status of the regional lymph nodes.

The primary objectives of this procedure are to achieve reliable detection of LNM in clinically unaffected lymph nodes and thus avoid unnecessary dissection and its complications and to provide optimal and timely selective surgical treatment.

The secondary objectives are optimal planning of adjuvant therapy and potentially reducing the risk of locoregional relapse.

The concept of SLN has become a standard in the detection of occult LNM in case of early breast cancer and skin melanoma. The effectiveness of the method was confirmed by its inclusion in the UICC TNM classification of malignant tumors $(17,18,19,20)$. 
Pioneering study of Kelemen and coworkers (1998) on SLN for thyroid nodules inducted a series of studies that have shown that SLN biopsy may be appropriate procedure in assessment of lymph node status in patients with differentiated thyroid cancer (21).

The concept involves mapping, detection and surical biopsy and their frozen-section and standard hi stopathologic analysis. The choice of markers (vital colors and/or nanocolloid), skills and experience of the surgeon in detecting (learning curve), the experience and knowledge of the pathologist in the processing of SLN are of key importance. The ratio of positive (malignant) and negative (benign) SLN presents the findings of sensitivity (Se), specificity (Sp), positive (PPV) and negative predictive value (NPV). On the basis of these findings overall accuracy of the method is calculated.

\section{RESULTS OF SLN BIOPSY FOR DIFFERENTIATED THYROID CANCER - REVIEW OF LITERATURE}

By 2012, three meta-analysis were published investigating the SLN techniques, the use of different markers and the results of methods accuracy of all relevant studies.

The first meta-analysis published by Raijmakers (2008), included 14 studies, of which in 10 were used the vital dye, and in four radiocolloid (Tc99m). The rate of SLN detection (identification rate, IR) in studies with vital dye was $83 \%$, and $96 \%$ in four studies with radiocolloid. The data on the sensitivity of the method were available in six of the 10 studies with a vital dye, and only one of the four studies with radiocolloid in which only a percentage of false negative results was available. Sensitivity in studies with vital dye was $87.3 \%$ (79 to $93 \%$ ) with a rate of false negative results of $12.7 \%$, versus $11.3 \%$ in the only study with radiocolloid. Histologically SLN somewhat questionable because several studies have included patients with benign thyroid tumors. Percentage of thyroid malignancy in seven studies ranged from 33 to $98 \%$, while in other studies, all patients had thyroid cancer. As a conclusion, with the real limitation, according to the detection of SLN in

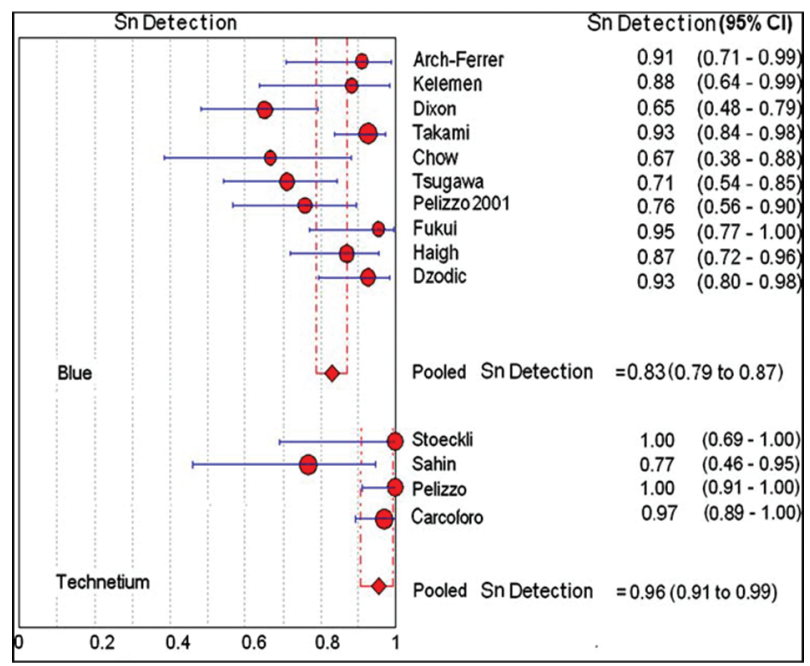

Figure 2. Detection rate of SLN in Raijmakers 'S meta-analysis

Source: Raijmakers P. G. H. M., Paul M. A., Lips P.

Sentinel node detection in patients with thyroid carcinoma: A meta-analysis. World J Surg (2008)

thyroid cancer is possible and potentially useful, but there is a need for new and more numerous prospective studies (22) (Figure 2).

The second meta-analysis by Balasubramanian and Harrison (2011) cover 24 relevant original studies on the role of SLN biopsy in thyroid cancer published until February 2010. In 17 studies vital dye was used as a marker, in four radiocolloid, while in the two studies, the combination of these two markers was used. Detection rate (IR) was $83.7 \%, 98.4 \%$ and $96 \%$ successively.

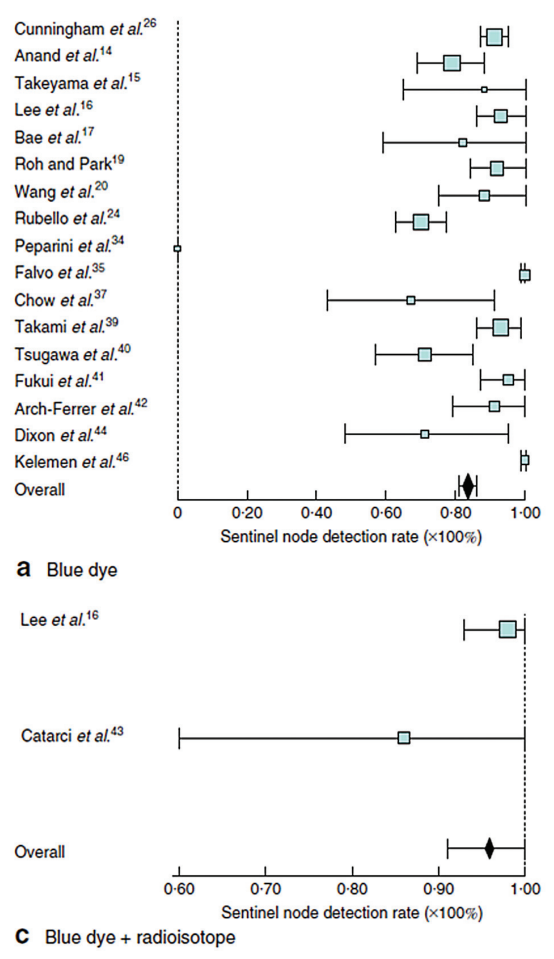

Fig. 3 Sentinel node detection rates with 95 per cent confidence intervals for techniques used by studies in the review: a blue dye, $\mathbf{b}$ radioisotope and $\mathbf{c}$ both blue dye and radioisotope
Figure 3. Detection rate of SLN in Balasubramanian's meta-analysis 


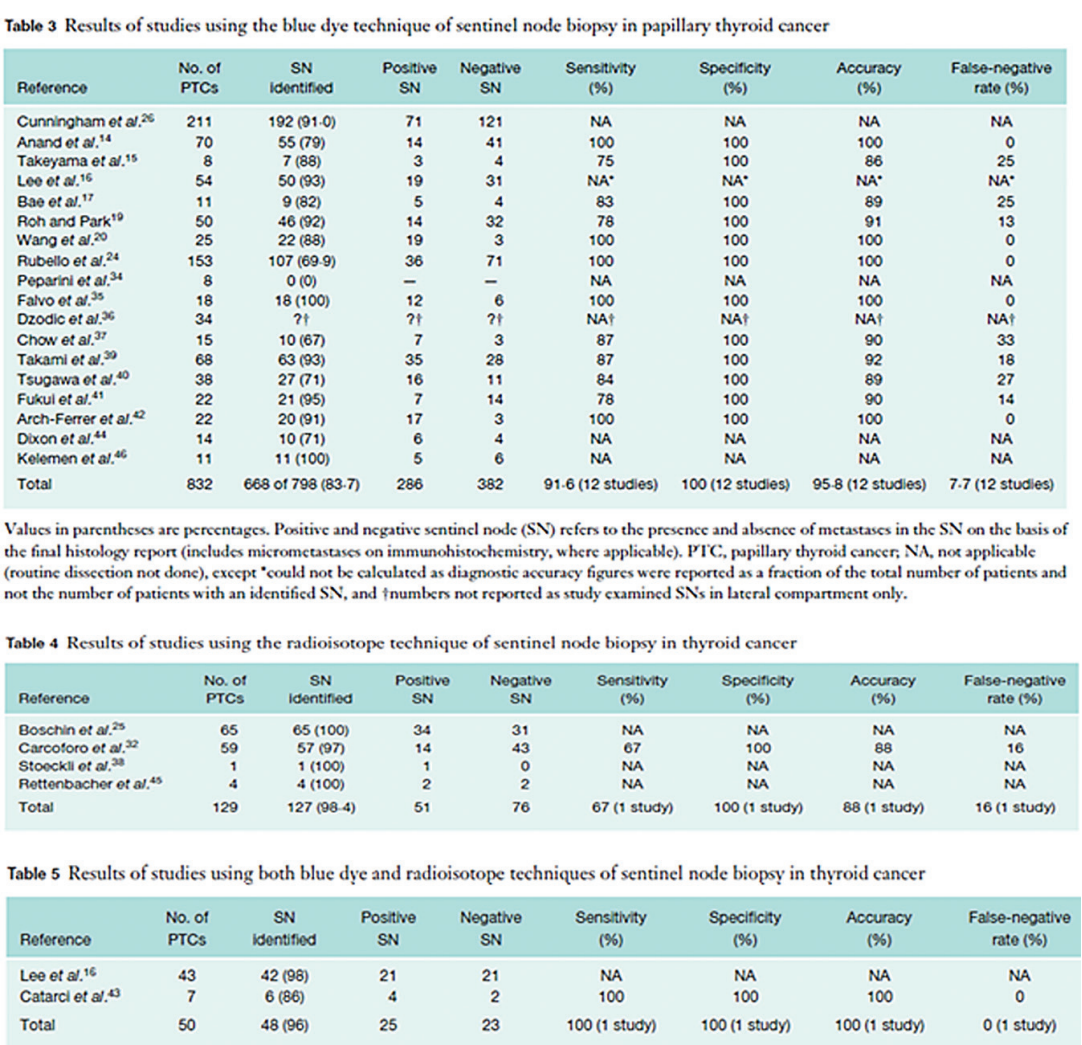

Figure 4. Results of studies with different markers used in Balasubramanianžs meta-analysis

Source: Balasubramanian S, Harrison B Systematic review and meta-analysis of sentinel node biopsy in thyroid cancer. Br J Surg (2011) into three groups. The first group of 18 study used the vital dye, in the second group of four studies, radiocolloid was used, and in the third group the two studies used a combined technique. SLN detection rate in patients was $83.1 \%$ in the first group, $98.8 \%$ in the second group and $97.8 \%$ in the third group. In two studies of the third group, Catarci have shown better result of detection with radiocolloid relative to the vital dye $(83.3 \%$ versus $50 \%)$, while Lee showed a better IR with vital dye (93\% versus $88.4 \%)(24,25,26)$.

This meta-analysis showed the advantage in IR of peritumoural injection of the vital dye compared to intratumoural application $(92.2 \%$ to $71.8 \%$ ). It also showed a better detection rate of SLN using methylene blue (Methylene blue), compared to isosulfan blue (Isosulfan blue) and patent blue (Patent blue) - $(91.9 \%$ versus $86.1 \%$ and $68.3 \%$ ). There were no differences in the rate of detection of intratumoral and peritu-
Analysis of sensitivity, specificity and overall accuracy of the method was possible in 12 studies with a vital stain, and only by one study with radiocolloid and combined method. The percentage of false negatives was successively $7.7 \%, 16 \%$ and $0 \%$. Lymph node metastasis in the SLN were observed in $42.9 \%$ of patients, whereas in eight studies, which is used for additional immunohistochemical analysis, micrometastases verified in another $14.8 \%$ of patients. Balasubramanian and Harrison concluded that $\mathrm{SLNb}$ method has high expectation and with its implementation can be avoided prophylactic dissection in almost $57 \%$ of patients with thyroid cancer and clinically negative lymph nodes (23) (Figures 3 and 4).

Finally, the third meta-analysis by Kaczka and associates (2012) included 25 studies, which according to the techniques of marking and detection of SLN was divided

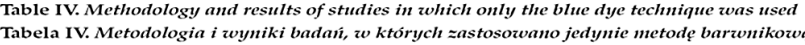

\begin{tabular}{|c|c|c|c|c|c|c|c|c|c|}
\hline No. 5 & $\begin{array}{l}\text { Study and } \\
\text { year }\end{array}$ & $\begin{array}{l}\text { Detection } \\
\text { technique }\end{array}$ & $\begin{array}{l}\text { Tracer volume } \\
\text { and dose }\end{array}$ & Injectionsite & $\begin{array}{c}\text { No of } \\
\text { pts }\end{array}$ & $\begin{array}{c}\begin{array}{c}\text { No. of } \\
\text { malignant } \\
\text { pts }\end{array} \\
\text {. }\end{array}$ & $\begin{array}{c}\text { No. of } \\
\text { pts with } \\
\text { detected } \\
\text { SLNs }\end{array}$ & $\begin{array}{c}\text { No. of } \\
\text { malignant pts } \\
\text { with detected } \\
\text { SLNs }\end{array}$ & $\begin{array}{c}\text { No. of malignant } \\
\text { pts with deteted } \\
\text { and metastatic } \\
\text { SLNs } \\
\end{array}$ \\
\hline $\begin{array}{ll}. \quad k \\
\end{array}$ & $\begin{array}{l}\text { Kelemen et al. } \\
1998[35]\end{array}$ & $\begin{array}{c}\begin{array}{c}\text { 1\% Isosulfan } \\
\text { blue dye }\end{array} \\
\text {. }\end{array}$ & $\begin{array}{c}0.1-0.8 \mathrm{~mL}, \\
\text { average } 0.5 \mathrm{~mL}\end{array}$ & Intratumoural & 17 & 12 & 15 & 12 & 5 \\
\hline $\begin{array}{l}2 . \quad 5 \\
\end{array}$ & $\begin{array}{l}\text { Dixon et al } \\
2000[40] \\
\end{array}$ & $\begin{array}{l}1 \% \text { Isosulfan } \\
\text { blue dye dye }\end{array}$ & $\begin{array}{c}0.1-0.8 \mathrm{~mL}, \\
\text { average } 0.7 \mathrm{~mL}\end{array}$ & Intratumoural & 40 & 15 & 26 & 11 & 7 \\
\hline $\begin{array}{ll}3 . \quad \\
\end{array}$ & $\begin{array}{l}\text { Arch-Ferrer } \\
\text { et al. 2001 [41] }\end{array}$ & $\begin{array}{c}1 \% \text { Isosulfan } \\
\text { blue dye }\end{array}$ & $0.5 \mathrm{~mL}$ & Intratumoural & 22 & 22 & 20 & 20 & 12 \\
\hline 4. $\quad 5$ & $\begin{array}{l}\text { Pelizzo et al. } \\
2001 \text { [42] }\end{array}$ & $\begin{array}{l}0.5 \% \text { Patent } \\
\text { Blue V }\end{array}$ & $0.5 \mathrm{~mL}$ & Intratumoural & 29 & 29 & 22 & 22 & 4 \\
\hline $\begin{array}{ll}5 . \quad 5 \\
\end{array}$ & $\begin{array}{l}\text { Fukui et al. } \\
2001 \text { [43] }\end{array}$ & $\begin{array}{l}2 \% \text { Methylene } \\
\text { blue }\end{array}$ & $\begin{array}{c}0.1 \mathrm{~mL} \\
4 \text { quadrant }\end{array}$ & Intratumoural & 22 & 22 & 21 & 21 & 7 \\
\hline 6. $\quad 7$ & $\begin{array}{l}\text { Tsugawa et al. } \\
2001[44]\end{array}$ & $\begin{array}{l}1 \% \text { Patent } \\
\text { blue dye }\end{array}$ & $0.2-0.5 \mathrm{~mL}$ & $\begin{array}{l}\text { Directly in the } \\
\text { thyroid mass }\end{array}$ & 38 & 38 & 27 & 27 & 16 \\
\hline $\begin{array}{ll}7 . \quad \\
\end{array}$ & $\begin{array}{l}\text { Takami et al. } \\
2003[45]\end{array}$ & $\begin{array}{l}\text { Isosulfan } \\
\text { blue dye }\end{array}$ & $0.3 \mathrm{~mL}$ & Peritumoural & 68 & 68 & 63 & 63 & 35 \\
\hline $8 . \quad 8$ & $\begin{array}{l}\text { Chow et al. } \\
2004 \text { [46] }\end{array}$ & $\begin{array}{c}2.5 \% \text { Patent } \\
\text { Blue V }\end{array}$ & $0.5-1 \mathrm{~mL}$ & Intratumoural & 15 & 15 & 10 & 10 & 7 \\
\hline 9. $\quad 5$ & $\begin{array}{l}\text { Peparini et al. } \\
2006 \text { [47] }\end{array}$ & $\begin{array}{l}2.5 \% \text { Patent } \\
\text { blue V }\end{array}$ & $\begin{array}{c}0.1-1.2 \mathrm{~mL} \\
\text { mean } 0.5\end{array}$ & $\begin{array}{l}5 \text { - intratumoural } \\
3 \text { - peritumoural }\end{array}$ & 8 & 8 & 0 & 0 & 0 \\
\hline 10. 5 & $\begin{array}{l}\text { Rubello et al. } \\
2006 \text { [48] }\end{array}$ & $\begin{array}{c}0.5 \% \text { Patent } \\
\text { blue V }\end{array}$ & $\begin{array}{c}0.25 \mathrm{~mL} \text { for } \\
1 \mathrm{~cm} \text { diameter }\end{array}$ & Intratumoural & 153 & 153 & 107 & 107 & 36 \\
\hline $\begin{array}{l}11.5 \\
\end{array}$ & $\begin{array}{l}\text { Dzodic et al. } \\
2006 \text { [49] }\end{array}$ & $\begin{array}{l}1 \% \text { Methylene } \\
\text { blue dye }\end{array}$ & $0.2 \mathrm{~mL}$ & Peritumoural & 40 & 40 & 37 & 37 & 9 \\
\hline 12. & $\begin{array}{l}\text { Abdalla et al. } \\
2006 \text { [50] }\end{array}$ & $\begin{array}{c}1 \% \text { Isosulfan } \\
\text { blue dye }\end{array}$ & $0.5-1 \mathrm{~mL}$ & Intratumoural & 30 & 0 & 18 & 0 & 0 \\
\hline 13. $\mathrm{F}$ & $\begin{array}{l}\text { Roh et al. } \\
2008[51]\end{array}$ & $\begin{array}{l}2 \% \text { Methylene } \\
\text { blue }\end{array}$ & $0.2 \mathrm{~mL}$ & Peritumoural & 50 & 50 & 46 & 46 & 18 \\
\hline 14. $\frac{1}{2}$ & $\begin{array}{l}\text { Wang et al. } \\
2008 \text { [52] }\end{array}$ & $\begin{array}{l}2 \% \text { Methylene } \\
\text { blue }\end{array}$ & $0.5 \mathrm{~mL}$ & Peritumoural & 25 & 25 & 22 & 22 & 19 \\
\hline 15. & $\begin{array}{l}\text { Bae et al. } \\
2009 \text { [50] }\end{array}$ & $\begin{array}{l}2 \% \text { Methylene } \\
\text { blue }\end{array}$ & $0.5 \mathrm{~mL}$ & $\begin{array}{l}\text { Intratumoural } \\
\text { and surrounding } \\
\text { parenchyma }\end{array}$ & 11 & 11 & 9 & 9 & 5 \\
\hline 16. $\mathrm{T}$ & $\begin{array}{l}\text { Takeyama } \\
\text { et al. } 2009[53]\end{array}$ & $\begin{array}{c}1 \% \text { Isosulfan } \\
\text { blue dye }\end{array}$ & $\begin{array}{c}0.1 \mathrm{~mL} \\
4 \text { quadrant }\end{array}$ & Peritumoural & 37 & 12 & 32 & 11 & 4 \\
\hline 17. $\frac{1}{2}$ & $\begin{array}{l}\text { Anand et al. } \\
2009 \text { [54] }\end{array}$ & $\begin{array}{c}1 \% \text { Methylene } \\
\text { blue }\end{array}$ & $0.2-0.3 \mathrm{~mL}$ & Peritumoural & $75^{*}$ & 75 & 70 & 70 & 15 \\
\hline 18. & $\begin{array}{l}\text { Cunningham } \\
\text { et al. } 2010 \text { [55] }\end{array}$ & $\begin{array}{l}1 \% \text { Isosulfan } \\
\text { blue dye }\end{array}$ & $0.5-2 \mathrm{~mL}$ & Intratumoural & 211 & 211 & 192 & 192 & 71 \\
\hline
\end{tabular}

Figure 5. Methodology and results of studies in which only blue dye was used in Kaczka's meta-analysis

Source: Kaczka K, Celnik A, Luks B, Jasion J, Pomorski L. Sentinel lymph node biopsy techniques in thyroid pathologies - a meta-analysis. Endokrynol Pol. (2012) 
moural applications of radiocollodi. Lymph node metastasis in the SLN were detected successively in $40.8 \%$, $39.9 \%$ and $52.1 \%$ of cases (24) (Figure 5).

Disparity of histopathological findings of primary thyroid tumor, involvement of benign tumors and cancers with different biological behavior, relatively few studies have been undertaken a complete surgical exploration of central and lateral neck compartmments and the lack of data on the statistical reliability of the testing methods, represent real constraints.

In the experimental study of $\mathrm{Li}$ and associates in laboratory rabbits, the advantage of methylene blue staining in speed, depth of penetration and persistence of staining compared to other vital colors have been shown (27).

Thevarajah and associates in the review paper analyzed the side effects and allergic reactions to the use of vital blue dye in the detection of SLN in breast cancer in the period from 1985 to 2002. They concluded that isosulfan blue cause significant allergic reactions, even life-threatening. Therefore, the use of methylene blue strongly recommended as an equally effective and safe alternative in the detection SLN (28).

The results of previous prospective study by Dzodic and associates (2006) are included in all three meta-analysis. Also, by 2011, our concept SLN biopsy in the lateral compartment was only published in the relevant literature. We used a $1 \%$ solution of methylene blue as peritumoral injection in 40 patients with thyroid cancer in the period from 2001 to 2004. Lymph node metastases in the lateral neck compartment were histologically confirmed in $22.5 \%$ of patients with clinically unaffected lymph nodes (cN0). SLN detection rate was $92.5 \%$, sensitivity $77.7 \%$, specificity $100 \%$, positive predictive value of $100 \%$, negative predictive value $94 \%$, while the overall accuracy of the method was $95 \%$ (29).

Unlike other studies that were based on the identification of the SLN biopsy in the central neck compartment, in this study the path of the vital dye was followed to the lymph nodes in lateral compartment with the idea to check them histologically in the case of metastases and perform selective lateral neck dissection.

During 2011, two studies that have analyzed rezltate $\mathrm{SLNb}$ lateral neck compartment were published. Ikeda presented the results of detection SLNb with Indocyanin green peritumoral application in 12 patients with PTC. The rate of detection was $100 \%$ as well as sensitivity, specificity and overall accuracy of the method. Lymph node metastases in the lateral compartment were confirmed in $50 \%$ of patients preoperatively staged as cN0 (30).
Lee and associates were included 94 patients with PTC, which had undergone SLN detection in the lateral compartment with intratumoral application of radiocolloid (Tc99m), preoperative lymphoscintigraphy and intraoperative hand held gamma probe. Detection rate was $63.8 \%$. The study included patients with PTC larger than $1 \mathrm{~cm}$ in diameter or evident central metastases. Lymph node metastases in the lateral compartment were confirmed in $31.7 \%$ of $\mathrm{cN} 0$ patients. Approximately $93 \%$ of SLN was located in the ipsilateral compartment in the level III and IV, $4.6 \%$ in level II and $2.3 \%$ in the third level. The sensitivity and accuracy of the method were not tested in this study (31).

\section{CONCLUSIONS AND PERSPECTIVES}

Based on the three meta-analysis it could be concluded that SLN biopsy is a safe and feasible, with high reliability in predicting occult lymph node metastases in differentiated thyroid carcinoma. Using vital dye is cheap and does not require technical equipment. The sensitivity of the method is increasing, while the complementary immunohistochemical and molecular techniques evolve. SLNb for thyroid cancer may prove practical use in precise staging of cervical lymph node status, detection LNM outside the central compartment, the selection of patients who will benefit with adequate and timely selective neck dissection and optimize application of ablative radioiodine therapy.

Currently, there is no direct evidence that SLNb could associated with long-term prognosis in terms of locoregional relapse and survival of patients with thyroid cancer.

Controlled prospective clinical studies on a larger number of patients and longer follow-up period will determine the clinical significance of occult LNM and their early detection method SLNb in patients with thyroid cancer.

\section{The authors have no conflict of interests.}
Abbreviations:
TC - Differentiated thyroid carcinoma
PTC - Papillary thyroid carcinoma
UICC - Union International Against Cancer
LNM - Lymph node metastases
ATA - American Thyroid Association
CND - Central neck dissection
MRND - Modified radical neck dissection
SLN - Sentinel lymph node
SLNB - Sentinel lymph node biopsy 


\title{
Sažetak
}

\section{KONCEPT STRAŽARSKIH LIMFNIH NODUSA KOD DIFERENTOVANOG TIROIDNOG KARCINOMA}

\author{
Marković Ivan, Džodić Radan \\ Medicinski fakultet Univerziteta u Beogradu, Institut za onkologiju i radiologiju Srbije, Beograd, Srbija
}

Diferentovani tiroidni karcinomi (DTK) čine do $90 \%$ svih tiroidnih maligniteta i najčešći su primarni maligniteti endokrinog sistema. Njihova učestalost je u značajnom porastu u poslednje tri decenije, a posebno malih papilarnih tiroidnih karcinoma (PTK). U vreme dijagnoze, učestalost limfonodalnih metastaza (LNM) iznosi od 80 do $90 \%$. U poslednjih 15 godina, LNM su prepoznate kao loš prognostički faktor za pojavu lokoregionalnog relapsa bolesti (LRR) i kancer-specifičnog preživljavanja. Postoji generalna saglasnost da su disekcije vrata indikovane kod klinički suspektnih LNM. Predmet aktuelnih kontroverzi predstavlja hirurški postupak sa okultnim LNM koje preoperativnom dijagnostikom ostaju neprepoznate (cN0). Opseg operacije na limfnim nodusima kreće se od teorije ,sačekati i videti“ takozvane ,zapadne škole“ argumentovane ulogom primene ablativne terapije J131 i učestalošću peroperativnih komplikacija (povrede povratnog

\section{REFERENCES}

1. CuradoMP, Edwards B, Shin HR et al. Cancer Incidence in Five Continents. IARC Scientific Publications, Vol. 9, No. 160, IARC, France, Lyon 2007.

2. Cooper DS, Doherty GM, Haugen BR et al. Revised American thyroid association management guidelines for patients with thyroid nodules and differentiated thyroid cancer.Thyroid. 2009 ; 19(11): 1167-214.

3. Hay ID, Thompson GB, Grant CS et al. Papillary thyroid carcinoma managed at the Mayo Clinic during six decades (1940-1999): temporal trends in initial therapy and long-term outcome in 2444 consecutively treated patients. World J Surg. 2002; 26(8): 879-85.

4. Machens A, Hinze R, Thomusch O, Dralle H. Pattern of nodal metastasis for primary and reoperative thyroid cancer. World J Surg.2002; 26(1): 22-8.

5. Podnos YD, Smith D, Wagman LD, Ellenhorn JD. The implication of lymph node metastasis on survival in patients with well differentiated thyroid cancer. Am Surg. 2005; 71(9): 731-4.

6. Lundgren CI, Hall P, Dickman PW, Zedenius J. Clinically significant prognostic factors for differentiated thyroid carcinoma: a population-based, nested case control study. Cancer. 2006; 106(3): 524-31.

7. Bhattacharyya N. Surgical treatment of cervical nodal metastases in patients with papillary thyroid carcinoma. Arch Otolaryngol Head Neck Surg. 2003; 129(10): 1101-4.

8. Simon D, Goretzki PE, Witte J, Röher HD. Incidence of regional recurrence guiding radicality in differentiated thyroid carcinoma. World J Surg. 1996; 20(7): 860-6. laringealnog nerva i hipoparatireoidizma) posebno kod manje iskusnih timova, do obostranih profilaktičkih disekcija centralne i lateralne regije vrata takozvane, ,japanske škole“ zbog ograničene upotrebe radioaktivnog joda u terapijske svrhe kao i značajno manjeg operativnog morbiditeta ukoliko se disekcija uradi u primarnom aktu. Uprkos visokoj prevalenci okultnih LNM, postojeće kontroverze u dijagnostici, dugoročnom prognostičkom značaju i opsegu operacija na limfnim nodusima, motivisale su neke autore da koncept provere stražarskih limfnih nodusa (SLN) primene kod pacijenata sa DTK, imajući u vidu odlične rezultate kod karcinoma dojke i melanoma kože. U ovom pregledu prikazani su sumirani rezultati relevantnih studija i tri meta analize pouzdanosti i primenljivosti konecpta SLN kod pacijenata sa diferentovanim tiroidnim karcinomom.

Ključne reči: Diferentovani tiroidni karcinom, limfonodalne metastaze, stražarski limfni nodusi.

9. Randolph GW, Duh QY, Heller KS, et al.The prognostic significance of nodal metastases from papillary thyroid carcinoma can be stratified based on the size and number of metastatic lymph nodes, as well as the presence of extranodal extension. Thyroid. 2012; 22(11): 1144-52.

10. Mazzaferri EL, Kloos RT. Clinical review 128:Current approaches to primary therapy for papillary and follicular thyroid cancer. J Clin Endocrinol Metab. 2001; 86(4): 1447-63.

11. Roh JL, Park JY, Park CI. Total thyroidectomy plus neck dissection in differentiated papillary thyroid carcinoma patients: pattern of nodal metastasis, morbidity, recurrence, and postoperative levels of serum parathyroid hormone. Ann Surg. 2007; 245(4): 604-10.

12. British Thyroid Association, Royal College of Physicians. Guidelines for the management of thyroid cancer (Perros P, ed) 2nd edition. Report of the Thyroid Cancer Guidelines Update Group. London: Royal College of Physicians, 2007.

13. Noguchi S, Yamashita H, Uchino S. Modified radical neck dissection is better than partial dissection of lymph nodes. World J Surg.2009; 33(3): 394-6.

14. Japanese Society of Thyroid Surgery - Japanese Society of Endocrine Surgeons. Guidelines for management of thyroid tumor. Tokyo: Kanehara; 2010.

15. Gould EA, Winship T, Philbin PH, Kerr HH.Observations on a "Sentinel Node" in cancer of the parotid. Cancer. 1960; 13: 77-8.

16. Cabanas RM. An approach for the treatment of penile carcinoma. Cancer. 1977; 39(2): 456-66.

17. Giuliano AE, Kirgan DM, Guenther JM, Morton DL. Lymphatic mapping and sentinel lymphadenectomy for breast cancer. Ann Surg. 1994; 220(3): 391-8; discussion 398-401. 
18. Morton DL, Wen DR, Wong JH, et al. Technical details of intraoperative lymphatic mapping for early stage melanoma. Arch Surg. 1992; 127(4): 392-9.

19. Krag DN, Weaver DL, Alex JC, Fairbank JT. Surgical resection and radio localisation of the sentinel node in breast cancer using gamma probe. Surg Oncol. 1993; 2(6): 335-9.

20. Sobin L.H., Gospodarowicz M., Wittekind C. eds. UICC: TNM classification of malignant tumors, 7th ed. New York: Wiley-Blackwell, 2010.

21. Kelemen PR, Van Herle AJ, Giuliano AE. Sentinel lymphadenectomy in thyroid malignant neoplasms. Arch Surg 1998; 133(3): 288-92.

22. Raijmakers PG,Paul MA, Lips P. Sentinel node detection in patients with thyroid carcinoma: A meta-analysis. World J Surg. 2008; 32(9): 1961-7.

23. Balasubramanian SP, Harrison BJ. Systematic review and meta-analysis of sentinel node biopsy in thyroid cancer. Br J Surg.2011; 98(3): 334-44.

24. Kaczka K, Celnik A, Luks B, Jasion J, Pomorski L. Sentinel lymph node biopsy techniques in thyroid pathologies a meta-analysis. Endocrynol Pol. 2012; 63(3): 222-31.

25. Catarci M, Zaraca F, Angeloni R.,et al. Preoperative Lymphoscintigraphy and Sentinel Lymph Node Biopsy in Papil- lary Thyroid Cancer. A Pilot Study. J. Surg Oncol. 2001; 77(1): 21-4.

26. Lee SK, Choi JH, Lim HI, et al. Sentinel lymph node biopsy in papillary thyroid cancer. Comparison study of blue dye method and combined radioisotope and blue dye method in papillary thyroid cancer. Eur J Surg Oncol. 2009; 35(9): 974-9.

27. Li X, Wang J, Zhou Z. Experimental study of sentinel node biopsy in thyroid by using three kinds of vital dyes at different concentration and dose (article in Chinese). Lin Chung Er Bi Yan Hou Tou Jing Wai Ke Za Zhi. 2007; 21(21): 988-90.

28. Thevarajah S, Huston TL, Simmons RM. A comparison of the adverse reactions associated with isosulfan blue versus methylene blue dye in sentinel lymph node biopsy for breast cancer. Am J Surg. 2005; 189(2): 236-9.

29. Dzodic R, Markovic I, Inic M, et al. Sentinel Lymph Node Biopsy May be Used to Support Decision to Perform Modified Radical Neck Dissection in Differentiated Thyroid Carcinoma. World J Surg. 2006; 30(5): 841-6.

30. Ikeda Y. Sentinel lymph node biopsy as guidance for lateral neck dissection in patients with papillary thyroid carcinoma. Surgical Science.2011; 2(2): 57-61.

31. Lee SK, Kim SH, Hur SM, Choe JH, Kim JH, Kim JS. The efficacy of lateral neck sentinel lymph node biopsy in papillary thyroid carcinoma. World J Surg. 2011; 35(12): 2675-82.

\section{Corresponding author/ Autor za korespondenciju}

Ivan Markovic, $\mathrm{MD}, \mathrm{PhD}$,

Medical faculty University of Belgrade, Institute of oncology and radiology of Serbia

Pasterova 14

11000 Belgrade

Serbia

Tel: +381637792716

Fax: +381112685300 